\title{
Institutional Distance and Foreign Direct Investment
}

\author{
Rafael Cezar ${ }^{\mathrm{a}}$, Octavio R. Escobar ${ }^{\mathrm{b}^{*}}$ \\ ${ }^{a}$ PSL-Université Paris-Dauphine, LEDa UMR 225-DIAL. Place du Maréchal de Lattre de \\ Tassigny, 75775 Paris, France. \\ ${ }^{b}$ ESG Management School. 25, rue Saint Ambroise, 75011 Paris, France.
}

\begin{abstract}
This paper studies the link between Foreign Direct Investment (FDI) and institutional distance. Using a heterogeneous firms framework, we develop a theoretical model to explain how institutional distance influences FDI and it is shown that institutional distance reduces both the likelihood that a firm will invest in a foreign country and the volume of investment it will undertake. We test our model, using inward and outward FDI data on OECD countries. The empirical results confirm the theory and indicate that FDI activity declines with institutional distance. In addition, we find that firms from developed economies adapt more easily to institutional distance than firms from developing economies.
\end{abstract}

Keywords: Foreign Direct Investment; institutions; heterogeneous firms; gravity model.

JEL: F12; F23; H80; K20.

\footnotetext{
* Corresponding author. Tel.: +33155289587.

E-mail addresses: oescobar@esg.fr (O.R. Escobar), rafael.cezar@dauphine.fr (R. Cezar).
} 


\section{Introduction}

Developing and transition economies increasingly attract Foreign Direct Investment (FDI) flows (UNCTAD, 2012). Three important patterns, observable in UNCTAD (2012) data, are helpful in understanding this trend. First, most FDI outflows are from developed economies, but their share in total FDI outflows is decreasing over time. Since 2003, the share of FDI outflows of developing and transition economies has consistently increased, reducing the share of FDI from developed economies to approximately $75 \%$ in 2011 . Second, firms primarily invest in countries with similar levels of development as their own. More than $70 \%$ of outward FDI from developing and transition economies goes to other developing and transition economies, and approximately $50 \%$ of this outward FDI goes to economies located in the source economy's region. Developed economies also locate most of their operations in other developed economies. Third, developed economies have a greater capacity to diversify their operations than developing and transition economies. Approximately $45 \%$ of outward FDI from developed economies goes to developing and transition economies. Moreover, developed economies are the main source of FDI in developing and transition economies.

Differences in the quality of institutions across countries are the main determinant of differences in economic development (Acemoglu and Robinson, 2010); we thus expect that institutional distance is an important determinant of FDI, and helps to explain recent FDI patterns. We develop a theoretical model, using a heterogeneous firms framework, to explain how institutional distance influences decisions to invest in a country and the volume of investment undertaken. According to the heterogeneous firms literature (Helpman et al., 2008; Yeaple, 2009), a productivity threshold must be overcome to make FDI profitable. Thus, only the most productive firms, mainly from developed countries, can invest abroad.

When entering foreign markets, multinational enterprises (MNEs) must adapt their strategies to the requirements of local institutions, which may differ from the institutions of their home countries. Our model suggests that MNEs face an adaptation cost in adjusting to the institutional environments of host countries. As adaptation costs increase with institutional distance, institutional distance 
determines the productivity threshold at which FDI is more profitable than exporting as a means of accessing foreign markets. Thus, increasing institutional distance reduces the number of firms that undertake FDI. In addition, adaptation costs reduce firm profits and the profitability of FDI. Accordingly, firms' FDI declines with institutional distance.

Firms perform better in foreign markets similar to their home markets than in markets that are dissimilar, as similarities are easier for firms to manage (Johanson and Vahlne, 2009). In addition to institutional similarities, development, geographical and cultural proximity are important determinants of FDI (Head and Ries, 2008; Helpman et al., 2008; Guiso et al., 2009). To control for differences in all of these factors across countries, when studying the determinants of FDI, the empirical literature uses gravity equations. Studies show that institutional distance matters for bilateral FDI. Differences between host and source countries in terms of corruption (Habib and Zurawicki, 2002), legal rules (Guiso et al., 2009), credit market regulations, legal constraints in recruiting and firing, and decentralisation of wage bargaining (Bénassy-Quéré et al., 2007) reduce bilateral FDI flows. However, the costs of institutional distance may differ for firms from developed and developing countries, owing to firm heterogeneity. Firms from developed countries may have more experience and better networks, which reduce the cost of institutional distance, than firms from developing countries (Johanson and Vahlne, 2009).

We proceed to an empirical validation of our model. Using alternative indicators of institutional distance, the results suggest that FDI activity declines as institutional distance increases. When investing in countries with weak institutions, firms from countries with weak institutions face lower costs than firms from countries with strong institutions. The results also suggest that institutional distance more strongly influences firms' decisions to invest in developing than in developed economies. Once investment decision is made, institutional distance equally affects the amount of investment from developed and developing economies.

This paper is organised as follows. Section 2 presents the theoretical model. Section 3 describes the empirical specification of the model and the estimation strategy. Section 4 describes the data and the 
measures of institutional distance used. The empirical results are presented in Section 5. Section 6 concludes.

\section{The model}

The model, based on Melitz (2003), Helpman et al. (2004) and Yeaple (2009), focuses on firms' arbitrage between exporting and producing abroad. The world economy features i countries with $\mathrm{N}$ firms in each. Each firm produces a single variety of good $\omega$ and is monopolistic in this variety. Consumer preferences, which are identical across countries, are represented by the following constant elasticity of substitution (CES) utility function:

$$
\mathrm{U}=\left(\int_{\omega \in \Omega_{\mathrm{i}}} \mathrm{q}(\omega)^{\frac{(\varepsilon-1)}{\varepsilon}} \mathrm{d} \omega\right)^{\varepsilon /(\varepsilon-1)}
$$

where $\varepsilon>1$ is the elasticity of substitution between goods and $\Omega_{\mathrm{i}}$ denotes the set of varieties available in country i. Maximisation of the utility function entails the following demand function for variety $\omega$ :

$$
\mathrm{q}_{\mathrm{i}}^{\mathrm{d}}(\omega)=\frac{\mathrm{p}_{\mathrm{i}}(\omega)^{-\varepsilon}}{\mathrm{P}_{\mathrm{i}}^{1-\varepsilon}} Y_{\mathrm{i}}
$$

where $p_{i}(\omega)$ is the price of variety $\omega, P_{i}=\left(\int p_{i}(\omega)^{1-\varepsilon} d \omega\right)^{1 /(1-\varepsilon)}$ is the ideal price index, and $Y_{i}$ is total income. The market is characterised by monopolistic competition, and the price of variety $\omega$ is a mark-up over marginal cost:

$$
\mathrm{p}_{\mathrm{i}}(\omega)=\frac{1}{\alpha} \mathrm{m},
$$

where $\alpha=\frac{\varepsilon-1}{\varepsilon}$ is a parameter that measures the inverse of the degree of differentiation between goods so that $\frac{1}{\alpha}$ indicates firms' unit margin, and $m$ is marginal cost.

Labour is the only input, and firms are heterogeneous in their firm-specific productivity levels, denoted by $\varphi$. This parameter indicates the quantity of goods produced with one unit of labour, and we 
assume that a cumulative distribution function (cdf) $\mu(\varphi)$, with support $\left[\varphi_{B}, \varphi_{H}\right]$, describes the

distribution of $\varphi$ across firms, where $\varphi_{\mathrm{H}}>\varphi_{\mathrm{B}}>0$, and $\varphi_{\mathrm{B}}$ and $\varphi_{\mathrm{H}}$ indicate the productivity levels of the least and most productive firms, respectively. The cdf is assumed to be identical across countries. Labour costs are country specific, with the wage in country i denoted by $w_{i}$. The marginal cost of output $\mathrm{w}_{\mathrm{i}} / \varphi$ is decreasing in productivity, constant at a given productivity level, and specific to each country.

\subsection{Costs of internationalisation}

The model focuses on firms' internationalisation decisions and only firms already operating in the domestic market are considered in the analysis. Firms wishing to sell their products abroad face a tradeoff between two internationalisation strategies: exporting or FDI that enables it to produce within the economy of its trading partner.

To export, firms face two additional costs: fixed and variable trade costs. Fixed trade costs relate to marketing, certifications, regulations, etc. These costs are bilateral and denoted by $f_{i j}$ for the pair $i, j$. Firms also face variable costs in selling their products abroad, modelled as iceberg transportation costs. Specifically, the delivery of one unit of a good in country j requires that $\tau_{\mathrm{ij}}>1$ units be shipped and the marginal cost of exporting from country $i$ to country $j$ is $\tau_{i j} w_{i} / \varphi$. These costs are country-pair specific. The total cost of exporting q units by a firm with productivity $\varphi$ is

$$
\mathrm{Cx}_{\mathrm{ij}}(\mathrm{q})=\mathrm{q}\left(\frac{\tau_{\mathrm{ij}} \mathrm{w}_{\mathrm{i}}}{\varphi}\right)+\mathrm{f}_{\mathrm{ij}}
$$

Firms can also open a subsidiary to produce directly in the destination country. This alternative allows a firm to economise on transportation costs but incurs management costs and high fixed costs related to the construction of new facilities and adaptation to the host country. The management and communication costs affect technology transfers and affect firms' productivities and marginal costs. These costs are modelled as iceberg costs with $\mathrm{T}_{\mathrm{ij}} \geq 1$. Therefore, the variable cost of FDI faced by a 
firm from country $i$ with productivity $\varphi$ and that produces in country $j$ is $w_{j} /\left(T_{i j}^{-1} \varphi\right)$. The fixed costs associated with this activity are $F_{i j}$. The total cost of producing q units in country $j$ is

$$
\operatorname{Cfdi}_{i j}(q)=q\left(\frac{w_{j}}{T_{i j}^{-1} \varphi}\right)+F_{i j}
$$

\subsection{Firms' arbitrage}

To focus on the tradeoff between exports and FDI, firms are assumed to only use FDI to access the host country's market. It is used neither as an export platform nor for outsourcing production. Transportation costs are assumed to be relatively high compared to the difference between labour costs and technology transfer costs (i.e., $\tau_{\mathrm{ij}} \mathrm{w}_{\mathrm{i}}>\mathrm{T}_{\mathrm{ij}} \mathrm{w}_{\mathrm{j}}$ for all country-pairs), and exporting fixed costs are always lower than FDI fixed costs (i.e., $F_{i j}>f_{i j}$ ).

From Equations 1 and 2, income from this activity can be represented as a function of firms' marginal costs. Specifically, $\mathrm{r}_{\mathrm{ij}}(\varphi)=\left(\alpha \mathrm{P}_{\mathrm{j}}\right)^{\varepsilon-1} \mathrm{Y}_{\mathrm{j}} \mathrm{m}(\varphi)^{1-\varepsilon}$ denotes income from sales to country $\mathrm{j}$ by a firm in country i with productivity $\varphi$, where $\mathrm{m}(\varphi)$ is the firm's marginal cost. The variable income of this project can also be represented as a function of marginal costs: $R_{i j}(\varphi)=\frac{r_{i j}}{\varepsilon}=\psi_{j} m(\varphi)^{1-\varepsilon}$, where $\Psi_{j}=\frac{\left(\alpha P_{j}\right)^{\varepsilon-1}}{\varepsilon} Y_{j}$ is specific to country $j$ and measures demand adjusted for the elasticity of substitution. Let us define $\pi_{\mathrm{x}}(\varphi)_{\mathrm{ij}}$ as export profits and $\pi_{\mathrm{I}}(\varphi)_{\mathrm{ij}}$ as FDI profits. They are, respectively:

$$
\begin{aligned}
& \pi_{x}(\varphi)_{i j}=\psi_{j}\left(\tau_{i j} w_{i}\right)^{1-\varepsilon} \varphi^{\varepsilon-1}-f_{i j} \\
& \pi_{I}(\varphi)_{i j}=\psi_{j}\left(T_{i j} w_{j}\right)^{1-\varepsilon} \varphi^{\varepsilon-1}-F_{i j} .
\end{aligned}
$$

Marginal costs are decreasing in $\varphi$; thus, $\mathrm{R}_{\mathrm{ij}}(\varphi)$ and profits are increasing in productivity, that is,

$\frac{\delta \mathrm{R}(\varphi)}{\delta \varphi}>0$ and $\frac{\delta \pi(\varphi)}{\delta \varphi}>0$, for both internationalisation strategies. Because firms only sell their products abroad if their profits are at least zero - that is, if variable income at least equals fixed costs two productivity thresholds can be defined. The first, denoted $\varphi_{\mathrm{x}}$, indicates the productivity level above which firms generate sufficient variable income to pay fixed export costs. The second, denoted 
$\varphi_{\mathrm{I}}$, indicates the productivity threshold above which firms can pay fixed FDI costs. These two thresholds are defined as $\pi\left(\varphi_{\mathrm{x}}\right)_{\mathrm{ij}}=0$ and $\pi\left(\varphi_{\mathrm{I}}\right)_{\mathrm{ij}}=0$, respectively. Firms with productivity levels equal to or greater than $\varphi_{\mathrm{x}}$ export, and all multinational firms have productivity at least equal to $\varphi_{\mathrm{I}}$.

The marginal cost of firms that export from country $i$ to $j$ is $\tau_{i j} w_{i} / \varphi$. The marginal cost of firms from country $\mathrm{j}$ that open a subsidiary in country $\mathrm{i}$ is $\left(\mathrm{T}_{\mathrm{ij}} \mathrm{w}_{\mathrm{j}}\right) / \varphi$. As $\tau_{\mathrm{ij}} \mathrm{w}_{\mathrm{i}}>\mathrm{T}_{\mathrm{ij}} \mathrm{w}_{\mathrm{j}}$ and $\varepsilon>1$, the variable income for MNEs - and their marginal profit - is always higher than the marginal income of exporting firms, as $\frac{\delta \pi_{\mathrm{I}}(\varphi)}{\delta \varphi}>\frac{\delta \pi_{\mathrm{X}}(\varphi)}{\delta \varphi}$. However, as fixed FDI costs are higher than fixed export costs, the productivity threshold above which firms will export is typically lower than the productivity threshold for FDI.

Figure 1 in the appendix illustrates the productivity thresholds and profits that determine whether firms export or engage in FDI. $\varphi_{\mathrm{I}}$ indicates productivity above which FDI is profitable. However, at this productivity level, exporting is more profitable than FDI. Production is moved abroad only if profits tereby generated exceed those of exporting, that is, if $\pi_{I}(\varphi) \geq \pi_{x}(\varphi)$. This threshold is represented in Figure 1 by $\varphi_{\mathrm{I}}^{*}$. Specifically, $\varphi_{\mathrm{I}}^{*}$ is such as $\pi_{\mathrm{I}}\left(\varphi_{\mathrm{I}}^{*}\right)=\pi_{\mathrm{x}}(\varphi)$ and represents the productivity of the marginal multinational firm. This productivity threshold is country-pair specific, and all firms in country $\mathrm{i}$ with productivity above $\varphi_{\mathrm{I}}^{*}$ produce directly in country $\mathrm{j}$.

As productivity levels are not observable, firms' income function is used as a proxy for the FDI threshold. Income is a good proxy for $\varphi$, as it is an increasing function of productivity. From Equation 3 , the income level above which firms from country $i$ invest (and produce) in country $j$ is

$$
r\left(\varphi_{I i j}^{*}\right)=\varepsilon \frac{\left(F_{i j}-f_{i j}\right)}{1-\left(\frac{\tau_{i j} w_{i}}{T_{i j} w_{j}}\right)^{1-\varepsilon}}
$$

All firms from country $\mathrm{i}$ with income levels higher than or equal to $r\left(\varphi_{\mathrm{I} \text { ij }}^{*}\right)$ engage in FDI in country $\mathrm{j}$.

As productivity follows the $\operatorname{cdf} \mu(\varphi)$ with $\varphi \in\left[\varphi_{B}, \varphi_{\mathrm{H}}\right]$, only the fraction $\left(1-\mu\left(\varphi_{\mathrm{I} i \mathrm{j}}^{*}\right)\right)$ of the $\mathrm{N}_{\mathrm{i}}$ 
firms from country i invest in country $\mathrm{j}$. Moreover, it is possible that this proportion equals zero if $\varphi_{\mathrm{I} i \mathrm{j}}^{*}>\varphi_{\mathrm{H}}$, with no firm sufficiently profitable to reach the threshold.

Equation 4 indicates that $\varphi_{\mathrm{I} \text { ij }}^{*}$ depends on the difference between the fixed costs of FDI and the fixed costs of exporting and on the ratio between the marginal costs of FDI and the marginal costs of exporting. An increase in fixed FDI costs raises the marginal income required to delocalise production and reduces the number of firms able to produce abroad. A reduction in fixed trade costs produces the same result. Specifically, an increase in the difference between $F_{i j}$ and $f_{i j}$ makes exports relatively more attractive than FDI.

As the ratio between marginal costs is always greater than one, $\left(\frac{\tau_{i j} w_{i}}{T_{i j} w_{j}}\right)^{1-\varepsilon}$ is less than unity. Therefore, $\varphi_{\mathrm{I} i \mathrm{j}}^{*}$ is larger when the distance between $\tau_{\mathrm{ij}} \mathrm{w}_{\mathrm{i}}$ and $\mathrm{T}_{\mathrm{ij}} \mathrm{w}_{\mathrm{j}}$ is small, while an increase in variable trade costs - such as customs barriers, poor infrastructure or distance - reduces the income threshold required to engage in FDI and raises FDI. Communication problems with the subsidiary or increasing labour costs in the host country have the opposite effect, reducing FDI.

Figure 1 divides firms into three distinct groups: i) firms with productivity below $\varphi_{\mathrm{x}}$ that produce only for the domestic market; ii) exporting firms with productivity between $\varphi_{\mathrm{x}}$ and $\varphi_{\mathrm{I}}^{*}$; and iii) MNEs with productivity of at least equal to $\varphi_{\mathrm{I}}^{*}$ that produce in the destination country through FDI ${ }^{1}$.

\subsection{Institutional distance and fixed FDI costs}

Firms face two types of fixed FDI costs: i) construction of new facilities, and ii) adaptation costs costs required to produce in the institutional, political and economic environment of the host country.

Equation 1 indicates that the demand of goods rises as price falls, and price - according to Equation 2 - decreases as firm productivity rises. Therefore, MNEs' demand depends on productivity, and the most productive firms face the highest demand, selling more goods in the host country. Subsequently,

\footnotetext{
${ }^{1}$ Both exporting firms and MNEs also produce in the source country for the domestic market.
} 
the size of the facilities that multinationals construct in the host country is proportional to their productivity level, with the most productive firms building the largest facilities.

Therefore, the cost of investment in new facilities is assumed to be a function of expected profits in the host market ${ }^{2}$. For simplicity, the investment cost function is assumed to be monotone and linear. The cost for firms of country $i$ of opening a subsidiary in country $j$ is $w_{j} \theta \pi_{i j}(\varphi)$, where the parameter $\theta$ is positive and strictly less than one, and $\pi_{i j}$ is defined as in Equation 3. Thus, the fixed cost of investing in new facilities depends on firm productivity.

The second fixed FDI cost is the adaptation investment in the new institutional environment. To produce in the host country, firms must adapt to its legal system, tax laws, political and governmental framework, conditions of access to credit, and regulations. Such adaptation costs depend on the institutional framework of the host country. Countries with weak institutional environments have high adaptation costs, while improvements in the institutional environment lower these costs (Daude and Stein, 2007). On the other hand, firms are already accustomed to the institutional environments of their domestic markets and have experience in coping with them. Such experience can reduce adaptation costs, especially when the institutional environments of the country-pair are similar (Bénassy-Quéré et al., 2007; Guiso et al., 2009; Habib and Zurawicki, 2002). Thus, institutional proximity between source and host countries reduces adaptation costs and facilitates FDI. A firm accustomed to a weak institutional environment will find it easier to invest in a country with similar characteristics, while the same firm will need to invest more to adapt to a country with an efficient institutional system.

Let us denote by $\lambda_{\mathrm{i}}$ the level of institutional development of country i. This parameter measures the overall institutional quality of a country, including regulations, property rights, access to information, financial constraints, level of corruption, and political stability, as well as the formalities involved in opening a business, executing a contract, and registering a property. If $\lambda_{\mathrm{i}}$ and $\lambda_{\mathrm{j}}$ represent the overall level of institutional development in the source and host countries, respectively, the cost of

\footnotetext{
${ }^{2}$ An alternative explanation is that the return on capital is calculated based on the sum of actualised expected profits.
} 
institutional adaptation is an increasing function of the distance between $\lambda_{\mathrm{i}}$ and $\lambda_{\mathrm{j}}$. When this distance is large, firms face strong institutional barriers, and adaptation costs are high. However, when institutional environments are similar, that is, when $\lambda_{\mathrm{i}}$ and $\lambda_{\mathrm{j}}$ are close, firms in country $\mathrm{i}$ are familiar with the institutional environment in country $\mathrm{j}$ and adaptation costs are low.

The adaptation cost associated with the institutional environment of country $\mathrm{j}$ for a firm from country $\mathrm{i}$ is denoted $w_{i} c\left(\lambda_{j}-\lambda_{i}\right)$, where the adaptation cost is measured in labour units of the source-country, as firms pay this cost in their own country before investing in the host country. The adaptation cost function is specific to the country-pair, monotone, strictly positive and increasing in institutional distance, such as $\frac{\delta c\left(\lambda_{\mathrm{j}}-\lambda_{\mathrm{i}}\right)}{\delta\left(\lambda_{\mathrm{j}}-\lambda_{\mathrm{i}}\right)}>0$.

The fixed cost of engaging in FDI in country $j$ for firms from country $i$ is

$$
F_{i j}=w_{j} \theta \pi_{i j}(\varphi)+w_{i} c\left(\lambda_{j}-\lambda_{i}\right)
$$

\subsection{Institutional distance and FDI margins}

From Equations 4 and 5, we can rewrite the income threshold above which firms from country i invest in country $j$ as

$$
r\left(\varphi_{\mathrm{I} i \mathrm{j}}^{*}\right)=\varepsilon \frac{\mathrm{w}_{\mathrm{j}} \theta \pi_{\mathrm{ij}}(\varphi)+\mathrm{w}_{\mathrm{i}} \mathrm{c}\left(\lambda_{\mathrm{j}}-\lambda_{\mathrm{i}}\right)-\mathrm{f}_{\mathrm{ij}}}{1-\left(\frac{\tau_{\mathrm{ij}} \mathrm{w}_{\mathrm{i}}}{\mathrm{T}_{\mathrm{ij}} \mathrm{w}_{\mathrm{j}}}\right)^{1-\varepsilon}}
$$

Equation 6 indicates a direct and negative relationship between institutional distance and the marginal variation in the proportion of firms that engage in FDI (extensive margin). On the one hand, an increase in institutional distance raises the income threshold and reduces the set of firms that are able to invest abroad. On the other hand, a decrease in institutional distance reduces adaptation costs and increases the number of firms that engage in FDI. This relationship is shown by

$$
\frac{\delta \varphi_{\mathrm{Iij}}^{*}}{\delta\left(\lambda_{\mathrm{j}}-\lambda_{\mathrm{i}}\right)} \approx \frac{\delta \mathrm{r}\left(\varphi_{\mathrm{Iij}}^{*}\right)}{\delta\left(\lambda_{\mathrm{j}}-\lambda_{\mathrm{i}}\right)}>0
$$


where $\delta \varphi_{\mathrm{I} i \mathrm{j}}^{*} / \delta\left(\lambda_{\mathrm{j}}-\lambda_{\mathrm{i}}\right)$ is the elasticity of the FDI productivity threshold with respect to institutional distance. This elasticity is positive, and so, a positive change in $\left(\lambda_{\mathrm{j}}-\lambda_{\mathrm{i}}\right)$ increases $\varphi_{\mathrm{I} i \mathrm{j}}^{*}$. An increase in the FDI productivity threshold reduces the proportion of MNEs (extensive margin) because $\mu(\varphi)$ is fixed and identical in all countries. This relationship is summarised in the following proposition:

Proposition 1: There is a direct and negative relationship between the institutional distance between countries and the marginal variation in the extensive margin, such as an increase in this distance raises the productivity threshold above which FDI is profitable and reduces the proportion of multinational firms in country $\mathrm{i}$ that invest in country $\mathrm{j}$.

To examine how institutional distance affects the volume of FDI between two countries (intensive margin), we define in the equation below $V_{i j}$ as the average productivity of firms from country $i$ that invest in country j:

$$
V_{i j}=\left\{\begin{array}{lll}
\int_{\varphi_{I}^{*} i j}^{\varphi_{H}} \varphi^{\varepsilon-1} \mathrm{~d} \mu(\varphi) & \text { if } \varphi_{I \text { ij }}^{*} \leq \varphi_{\mathrm{H}} \\
0 & \text { if } \varphi_{\mathrm{I} i \mathrm{j}}^{*}>\varphi_{\mathrm{H}}
\end{array}\right.
$$

If $\varphi_{\mathrm{I} i \mathrm{j}}^{*}>\varphi_{\mathrm{H}}, \mathrm{V}_{\mathrm{ij}}=0$ because the productivity threshold is higher than the productivity of the most productive firm, and no firm from country $i$ is sufficiently productive to invest in country $j$. When $\varphi_{\mathrm{I} i \mathrm{j}}^{*} \leq \varphi_{\mathrm{H}}$, at least one firm has productivity sufficient to invest abroad, and $\mathrm{V}_{\mathrm{ij}}>0$. This variable is country-pair specific, with $\mathrm{V}_{\mathrm{ij}} \neq \mathrm{V}_{\mathrm{ji}}$, which allows for asymmetric FDI flows.

The intensive margin is the sum of all investments made by each firm (for which $\varphi \geq \varphi_{\mathrm{I} \text { ij }}^{*}$ ) in the construction of new facilities ${ }^{3}$. From Equations 5 and 8, total FDI from country $i$ to country $j$ is

$$
\begin{aligned}
\operatorname{FDI}_{i j} & =w_{j} \theta \pi_{i j}(\varphi) V_{i j} N_{i} \\
& =\left(\frac{\left(1-w_{j} \theta\right) w_{j} \theta}{1-\left(w_{j} \theta\right)^{2}}\right)\left(\Psi_{j}\left(T_{i j} w_{j}\right)^{1-\varepsilon} \varphi^{\varepsilon-1}-w_{i} c\left(\lambda_{j}-\lambda_{i}\right)\right) V_{i j} N_{i}
\end{aligned}
$$

\footnotetext{
${ }^{3}$ As adaptation cost is incurred in the source country before investments are complete, FDI exclusively concerns investments in new facilities.
} 
Equation 9 indicates that the cost of institutional adaptation has a negative effect on the value of FDI, and a positive change in the first variable reduces FDI from country $i$ to country j. $c\left(\lambda_{j}-\lambda_{i}\right)$ also affects the number of investing firms via the productivity threshold, which is included in $V_{i j}$. Thus, institutional distance affects the intensive margin of FDI through these two distinct channels. Based on these observations, the second theoretical proposition is presented as follows:

Proposition 2: Institutional distance negatively affects the intensive margin of FDI, such as an increase in institutional distance reduces FDI.

\section{Empirical specification}

The gravity equation is commonly used to study the determinants of FDI as they can be derived from various theoretical models (Head and Ries, 2008; Kleinert and Toubal, 2010). We develop a gravity equation to test the propositions of our model. First, our model suggests that institutional distance influences decisions to invest abroad (the extensive margin). Second, our model suggests that institutional distance influences the profitability of foreign investment and the volume of investment

(the intensive margin). Because the volume of investment depends on the extensive margin, we develop, following Helpman et al. (2008), a two-stage gravity equation to estimate the extensive and intensive margins. In the first stage, or selection equation, firms choose whether to invest (extensive margin); in the second stage, or primary equation, firms that invest decide how much to invest (intensive margin).

\subsection{Empirical specification of the selection equation}

From Equation 8, the decision to invest depends on firms' productivity and on the productivity threshold. We define the variable $\mathrm{Z}_{\mathrm{ij}}$ as the ratio of the productivity of the most productive firm $\left(\varphi_{\mathrm{H}}\right)$ to the productivity threshold $\left(\varphi_{\mathrm{I} i \mathrm{j}}^{*}\right)$. If $\mathrm{Z}_{\mathrm{ij}}>1$, then firms from country $\mathrm{i}$ invest in country $\mathrm{j}$. We assume that the productivity of the most productive firm $\left(\varphi_{\mathrm{H}}\right)$ in country $i$ is given; thus, variations in $\mathrm{Z}_{\mathrm{ij}}$ are caused by changes in the threshold at which FDI is more profitable than exports. Therefore, the 
estimation of $\mathrm{Z}_{\mathrm{ij}}$ allows us to estimate the impact of institutional distance on the productivity threshold $\left(\varphi_{\mathrm{I} \text { ij }}^{*}\right)$ and the decisions of firms to invest abroad:

$$
\mathrm{Z}_{\mathrm{ij}}=\left(\frac{\varphi_{\mathrm{H}}}{\varphi_{\mathrm{I} i \mathrm{j}}^{*}}\right)^{\varepsilon-1}=\frac{\left(\frac{\left(\alpha \mathrm{P}_{\mathrm{j}}\right)^{\varepsilon-1}}{\varepsilon} \mathrm{Y}_{\mathrm{j}}\right)\left(\left(\mathrm{T}_{\mathrm{ij}} \mathrm{w}_{\mathrm{j}}\right)^{1-\varepsilon}-\left(\tau_{\mathrm{ij}} \mathrm{w}_{\mathrm{i}}\right)^{1-\varepsilon}\right)}{\mathrm{F}_{\mathrm{ij}}-\mathrm{f}_{\mathrm{ij}}} \varphi_{\mathrm{H}}^{\varepsilon-1} .
$$

We assume that differences in fixed and variable costs between exporting and FDI are stochastic. More precisely, we suppose that $\left(T_{i j} w_{j}\right)^{1-\varepsilon}-\left(\tau_{i j} w_{i}\right)^{1-\varepsilon} \equiv \exp \left(\vartheta_{1} w_{i}+\vartheta_{2} w_{j}+\vartheta_{3} X_{i}+\vartheta_{4} M_{j}+\right.$ $\left.\vartheta_{5} Y_{i j}+\epsilon_{i j}\right)$, where $X_{i}$ is a measure of the costs of exporting, such as customs procedures and regulations in country $i$, and is independent from the export destination; $M_{j}$ is a measure of trade barriers, such as customs procedures and regulations, imposed by the importing country $\mathrm{j}$ on all exporters; $\Upsilon_{\mathrm{ij}}$ measures country-pair characteristics, such as bilateral distance and ease of communication, that influence both trade costs $\left(\tau_{\mathrm{ij}}\right)$ and coordination costs $\left(\mathrm{T}_{\mathrm{ij}}\right)$; and $\epsilon_{\mathrm{ij}} \sim \mathrm{N}\left(0, \sigma_{\epsilon}^{2}\right)$ is an error term. With respect to differences in fixed costs, we assume that $F_{i j}-f_{i j} \equiv \exp \left(\beta_{1} w_{i}+\right.$ $\left.\beta_{2} \mathrm{w}_{\mathrm{j}}+\beta_{3} \mathrm{c}\left(\lambda_{\mathrm{j}}-\lambda_{\mathrm{i}}\right)+\xi_{\mathrm{ij}}\right)$, where $\xi_{\mathrm{ij}} \sim \mathrm{N}\left(0, \sigma_{\xi}^{2}\right)$ is an error term. We can express Equation 10 in log form as

$$
z_{i j}=\gamma_{0}+\gamma_{i}+\gamma_{j}+\gamma_{i j}+\eta_{i j}
$$

where $\mathrm{z}_{\mathrm{ij}}=\ln \left(\mathrm{Z}_{\mathrm{ij}}\right) ; \gamma_{0}=(\varepsilon-1) \ln (\alpha)-\ln (\varepsilon)$ is a constant; $\gamma_{\mathrm{i}}=(\varepsilon-1) \ln \left(\varphi_{\mathrm{H}}\right)+\left(\vartheta_{1}+\beta_{1}\right) \mathrm{w}_{\mathrm{i}}+$ $\vartheta_{3} X_{i}$ represents the characteristics of the source country $i ; \gamma_{j}=(\varepsilon-1) \ln \left(P_{j}\right)+\ln \left(Y_{j}\right)+\left(\vartheta_{2}+\right.$ $\left.\beta_{2}\right) w_{j}+\vartheta_{4} M_{j}$ represents the characteristics of the host country $j ; \gamma_{i j}=\vartheta_{5} \Upsilon_{i j}+\beta_{3} c\left(\lambda_{j}-\lambda_{i}\right)$ represents the characteristics of the country-pair $i, j$; and $\eta_{i j}=\epsilon_{i j}+v_{i j} \sim N\left(0, \sigma_{\epsilon}^{2}+\sigma_{\xi}^{2}\right)$ is an independent and identically distributed (iid) error term.

We cannot measure $\mathrm{z}_{\mathrm{ij}}$ because neither firms' productivity levels nor the productivity threshold are observable. However, the presence of firms from country $i$ in country $j$ implies that $z_{i j}>0$. A selection indicator $S_{i j}$ is generated, using a latent variable such as $S_{i j}=1$ if firms from country $i$ invest 
in country $\mathrm{j}$ and $\mathrm{S}_{\mathrm{ij}}=0$ otherwise. Let $\rho_{\mathrm{ij}}$ be the probability that country $\mathrm{i}$ invests in country $\mathrm{j}$, conditional on the observed variables. Assuming $\sigma_{\eta}^{2}=\sigma_{\epsilon}^{2}+\sigma_{v}^{2}=1$, we can specify Equation 11 as a probit equation:

$$
\begin{array}{r}
\rho_{\mathrm{ij}}=\operatorname{Pr}\left(\mathrm{S}_{\mathrm{ij}}=1 \mid \text { Observed variables }\right) \\
=\Phi\left(\gamma_{0}+\gamma_{\mathrm{i}}+\gamma_{\mathrm{j}}+\gamma_{\mathrm{ij}}+\eta_{\mathrm{ij}}\right),
\end{array}
$$

where $\Phi(\cdot)$ is the cumulative distribution function of the unit-normal distribution. We then estimate the predicted value of $z_{i j}$ as $\hat{z}_{i j}=\Phi^{-1}\left(\hat{\rho}_{i j}\right)$. It is important to note that the selection equation (Equation 12), is derived from a decision at the firm level. It shows how changes in the characteristics of the countries affect FDI decisions. More specifically, marginal changes in the characteristics of country i or $\mathrm{j}$ modify the productivity threshold and affect the choice between exporting or performing FDI. Equation 12 then provides information on the marginal variation in the proportion of firms from country i investing in country $j$.

\subsection{Empirical specification of the primary equation}

FDI flows from country i to country $\mathrm{j}$, given by Equation 9, can be expressed in $\log$ form as $\ln \left(\mathrm{FDI}_{\mathrm{ij}}\right)=\theta+\ln \left(\mathrm{w}_{\mathrm{j}}\right)+\ln \left(\pi_{\mathrm{ij}}\right)+\ln \left(\mathrm{V}_{\mathrm{ij}}\right)+\ln \left(\mathrm{N}_{\mathrm{i}}\right)$. Profits $\left(\pi_{\mathrm{ij}}\right)$ depend on demand as well as on production and implantation costs. Thus, we estimate the following equation

$$
\ln \left(\mathrm{FDI}_{\mathrm{ij}}\right)=\phi+\phi_{\mathrm{i}}+\phi_{\mathrm{j}}+\phi_{\mathrm{ij}}+\mathrm{v}_{\mathrm{ij}}+\mathrm{u}_{\mathrm{ij}}
$$

where $\phi_{\mathrm{i}}, \phi_{\mathrm{j}}$, and $\phi_{\mathrm{ij}}$ are the characteristics of country $\mathrm{i}$, country $\mathrm{j}$, and country-pair $\mathrm{i}, \mathrm{j}$, respectively; $\mathrm{v}_{\mathrm{ij}}=\ln \left(\mathrm{V}_{\mathrm{ij}}\right)$ is the logarithm of the average productivity level of firms from country $\mathrm{i}$ that invest in country $\mathrm{j}$; and $\mathrm{u}_{\mathrm{ij}} \sim \mathrm{N}\left(0, \sigma_{\mathrm{u}}^{2}\right)$ is an error term. 
From Equations 4 and 7, following Helpman et al. (2008), we specify $\mathrm{v}_{\mathrm{ij}} \equiv \mathrm{v}\left(\mathrm{z}_{\mathrm{ij}}\right)$ as an arbitrary increasing function of $\mathrm{z}_{\mathrm{ij}}$. More precisely, we control for $\mathrm{E}\left[\mathrm{V}_{\mathrm{ij}} \mid ., \mathrm{S}_{\mathrm{ij}}=1\right]$, using $\mathrm{v}\left(\hat{\mathrm{z}}_{\mathrm{ij}}\right)$, which we approximate with a cubic polynomial in $\hat{\mathrm{z}}_{\mathrm{ij}}$.

\subsection{Estimation strategy}

Equations 12 and 13 include common exogenous variables specific to the FDI source country i, host country j, and country-pair i,j. GDP per capita proxies for wage levels, geographical and cultural distance proxy for trade and coordination costs, and country size or GDP levels proxy for demand. These proxies enable us to construct a gravity equation for both the selection and primary equations. The literature suggests that under general equilibrium, bilateral FDI depends on the same exogenous determinants as bilateral trade flows (Bergstrand and Egger, 2007; Egger, 2010).

Although the exogenous variables included in the selection and primary equations may be identical, an additional variable not included in the primary equation is also required in the selection equation (Wooldridge, 2002). In addition, incorporating panel data estimates from the selection equation into the primary equation entails potential autocorrelation bias. We follow Wooldridge (2002), who proposes estimating the selection equation for each year $t$ and using the resulting estimates to compute $\hat{\mathrm{z}}_{\mathrm{ij}}$. This procedure is similar to the two-stage estimators of Heckman (1979); however, we only control for firms' heterogeneity, not for selection bias. To address zero flow observations, we employ the Santos-Silva and Tenreyro (2010) Poisson pseudo-maximum-likelihood (PPML) estimator.

\section{Data}

We construct a panel database of the bilateral relationships between 31 OECD countries and 125 countries in different stages of economic development. Data are available for the 2004-2009 period. The dependent variable is the ratio of the bilateral stock of foreign direct investment - inward into and outward from OECD countries - to the GDP of the FDI receiving country ${ }^{4}$. Data come from the

\footnotetext{
${ }^{4}$ FDI stock data are widely used in the literature. The most frequent arguments used to justify the use of FDI stock data are as follows: (i) FDI is also financed by markets in the host country, and therefore, stock data
} 
International Direct Investment Statistics database, available from the OECD, and from the World Development Indicators (WDI) of the World Bank. WDI also provides data on GDP per capita. Geographic and cultural variables are available from the Center for Studies, Prospective and International Information (CEPII).

\subsection{Institutional distance index}

Different institutional frameworks and their impact on economic activity have received substantial attention in the recent literature on FDI (Bénassy-Quéré et al., 2007; Guiso et al., 2009). Generally, the term "institution" refers to structures that affect economic relations. North (1993) defines institutions as the constraints built by men and designed to organise social relations. Formal constraints include regulations, property rights, the financial system and contract enforcement (Levchenko, 2007); while informal constraints include levels of social trust (Algan \& Cahuc, 2010) and corruption (Habib \& Zurawicki, 2002).

A measure of the distance between institutional environments must therefore be sensitive to various aspects of the institutional structures of each country. Thus, a wide range of indicators of various formal and informal constraints is used to construct a single composite index for each country in the sample, using principal component analysis (PCA). The institutional indexes of countries i and $\mathrm{j}$ are denoted by $\lambda_{\mathrm{i}}$ and $\lambda_{\mathrm{j}}$. The institutional distance between two countries is then calculated from the composite index and equals the absolute value of the difference between two countries' indices:

$$
\operatorname{Dist}_{i j}=\left|\lambda_{i}-\lambda_{j}\right|
$$

\subsubsection{Principal component analysis}

Principal component analysis is used to construct the composite institutional index. This method allows for a set of multivariate observations to be described by a linear combination of these observations so as to maximise the variance explained by the new variable. Specifically, the original

provide a more accurate measure than flow data; (ii) Stocks are much less volatile than flows; and (iii) Stock data greatly reduce the number of zero observations in the sample. 
variables $x_{1 i}, \ldots, x_{n i}$ are transformed into a new variable $y$, such that the variance of $y$ in the total sample is maximal. In other words, the weighting coefficients of the first component maximise the variance and minimise the loss of information from the original sample $\mathrm{e}^{5}$.

We estimate the institutional index using the first component of the analysis. This component alone explains approximately $68 \%$ of the total variance in the sample constructed ${ }^{6}$, a high level of explanatory power that fully justifies the use of this component to summarise the information contained in the various selected variables.

\subsubsection{Institutional data}

We use 13 indicators of the efficiency of structures that affect economic relations to measure the functioning of the economic and institutional environment. Two different composite indicators are constructed from the combination of these variables, and one distance measure is constructed for each indicator (see Table 1).

The first institutional index we construct is composed of six indicators. Among these, four indicators measure the quality of governments and their policies: corruption index, government effectiveness, political stability, and regulatory quality. The first captures the extent to which public power is exercised for private gain. The second is sensitive to the quality of public services, their independence from political pressure and the credibility of government commitments. Political stability indicates views about the probability that a government could be destabilised or overthrown by unconstitutional or violent means. The final indicator measures the ability of government to formulate and implement policies and regulations that promote development of the private sector. These indicators are made available by the World Governance Indicators project of the World Bank. Two additional variables, which also measure the quality of regulatory policy and the institutional environment faced by firms and their access to information, are employed in the construction of this first index. Credit rights

\footnotetext{
${ }^{5}$ As the growth of these coefficients increases the variance indefinitely, the sum of the squared coefficients is constrained to equal unity. Furthermore, to address the different scales and units of the variables, the initial sample is centred-reduced, such that the mean is equal to zero and the standard deviation is equal to one.

${ }^{6}$ For index $1,68 \% ; 40 \%$ in index 2 .
} 
measures the degree to which collateral and bankruptcy laws protect the rights of borrowers and lenders and thus the functioning of the credit market. The Information index measures rules affecting the scope, accessibility, and quality of information available through either public or private credit registries. These two variables are made available by the Doing Business project of the World Bank.

The second institutional index is composed of the six indicators presented below and seven others ${ }^{7}$. Three of the indicators concern bureaucratic practices and laws imposed on businesses: the costs of executing a contract, of registering a property and of starting a business. Two other indicators measure trade institutions: cost to export and cost to import, both measured as cost per container in U.S. dollars. These five indicators are provided by the World Bank's Doing Business project. An additional indicator is employed to measure governments' protectionist policies: the simple mean applied tariff rate, as a percentage of price, for all traded goods. This indicator is calculated in the Global Development Indicators, using data from the Trade Analysis and Information System of the United Nations and the Integrated Data Base of the World Trade Organization. The seventh measure used is the private credit to GDP ratio, which indicates the financial resources provided to the private sector through loans, purchases of non-equity securities, and trade credits. This variable indicates financial constraints in the economy and is provided by the International Monetary Fund. ${ }^{8}$

\section{Results}

Our model suggests that institutional distance reduces both the extensive and intensive margins of FDI. This section presents empirical results that verify the propositions of the model, using two alternative datasets. The first uses data on OECD countries' outward FDI, while the second uses data on the OECD countries' inward FDI. We find differences between the determinants of outward and

\footnotetext{
${ }^{7}$ The main criterion used in selecting variables and in their division into the two composite indexes is the availability of data.

${ }^{8}$ An increase in all 13 indicators employed in both indexes indicates development of the institutional environment, such that an increase in the two composite indexes proposed in this section indicates an improvement in institutional quality. Nevertheless, this is not the objective of this exercise, which is mainly to measure the difference in institutional environments across countries.
} 
inward FDI, differences that help explain the contrasting patterns of FDI outflows between developing and developed countries.

\subsection{Determinants of OECD countries' outward FDI}

First, we nominated an exogenous variable correlated with the selection indicator $S_{i j}$ but not with FDI stocks. Column 1 of Table 2 shows that the contiguity dummy variable and the colonial tie dummy variable are good candidates for such a variable, as they are not significantly correlated with FDI. The estimates of the probit model indicate that the colonial tie dummy variable is significantly correlated with the selection indicator, but the contiguity dummy is not. Thus, we use the colonial tie dummy variable as an exogenous variable in the selection equation and not in the primary equation.

Column 2 presents the probit estimates of the selection equation, or the extensive margin. The results indicate that GDP per capita in the source country, similarity in size between the countries, common language, and colonial ties increase the number of firms from country $\mathrm{i}$ investing in country $\mathrm{j}$, but geographical and institutional distance reduce this number. This result is robust to estimates based on the second index of institutional distance (column 4).

The probit estimates provide information regarding the main determinants of the extensive margin. However, using these estimates can lead to serious bias when estimating the primary equation, or the intensive margin (Wooldridge, 2002). We estimate the parameter for the number of MNEs from country $i$ in country $j\left(\hat{z}_{i j}\right)$, using different probit estimates for each year $t$. We then add $\hat{z}_{i j}$ to the primary equation to estimate the determinants of the amount of FDI, or the intensive margin. Column 3 presents the results for the primary equation, using the first index of institutional distance. On the one hand, bilateral FDI increases in the number of investing firms $\left(\hat{\mathrm{z}}_{\mathrm{ij}}\right)$, GDP per capita of both the source and host countries, similarity in size and common language. On the other hand, bilateral FDI declines with both geographical and institutional distance. Like the probit estimates, the PPML estimates are quite similar for the second index of institutional distance presented in column 5. 
The results show similar determinants of the intensive margin (selection equation) and the extensive margin (primary equation). However, the extensive margin is more sensitive to similarities in GDP level, common language, and institutional distance, but less sensitive to geographical distance. GDP per capita of the host country is not significant for the intensive margin but is significant for the extensive margin. However, similar GDP levels are more important than the host country's GDP per capita.

\subsection{Determinants of OECD countries' inward FDI}

We proceed to estimate the results using inward FDI instead of outward FDI. The results are presented in Table 3. First, we identify an exogenous variable correlated with $S_{\mathrm{ij}}$ and not with $\mathrm{FDI}_{\mathrm{ij}}$. Column 1 indicates that the colonial ties dummy is not correlated with FDI. Thus, we use the colonial ties variable as an exogenous variable in the selection equation, but we exclude it from the primary equation.

Columns 2 and 4 present the probit estimates of the selection equation. The likelihood that a firm from country $\mathrm{i}$ invests in country $\mathrm{j}$ increases with similarities in size and culture, but this likelihood decreases with geographical and institutional distance. The results are robust to changing the institutional index. Institutional distance reduces the number of firms that engage in FDI, as suggested by the model.

We estimate $\hat{\mathrm{z}}_{\mathrm{ij}}$ using different probit estimates for each year $\mathrm{t}$; we then add $\hat{\mathrm{z}}_{\mathrm{ij}}$ to the primary equation to estimate the determinants of FDI volume. Columns 3 and 5 indicate that FDI volume also increases in the number of MNEs, GDP per capita of the host country, similarities in size between the source and host countries and common language but declines in geographical and institutional distance. Among these variables, only GDP per capita is not correlated with the selection indicator. More importantly, the extensive margin is more sensitive than the intensive margin to GDP and language similarities but less sensitive to geographical distance. The difference in sensitivity to institutional distance between the two margins is, however, small. 


\subsection{Institutional distance and FDI patterns}

The results, presented in Tables 2 and 3, highlight similarities and differences in the patterns of outward and inward FDI. GDP per capita of the host economy increases the volume of FDI but does not affect the likelihood that new firms will engage in both outward and inward FDI. Average income in the host economy appears to increase the profitability of investment, which encourages firms to undertake the largest investments in the most developed countries.

GDP per capita of the source country is very important in outward FDI of OECD countries but insignificant in inward FDI. The wealthiest OECD countries are present in more countries and invest larger amounts than less developed OECD countries. OECD countries also attract FDI from various locations but not necessarily from the most developed countries.

Similarities in economic size and culture increase both the number of investing firms and the volume of FDI. Similarity of GDP levels is, however, a stronger determinant of inward FDI than of outward FDI. As OECD countries are among the largest economies in the world, this result suggests that among non-OECD countries, differences in the investment capacities between small and large countries are larger than differences in the abilities of small and large countries to attract FDI from OECD countries.

As our model suggests, institutional distance influences which firms will engage in FDI, or the extensive margin. However, the costs of institutional distance for developed and developing countries are asymmetric. OECD inward FDI is more sensitive to institutional distance than OECD outward FDI. According to our model, institutional distance is a cost that increases the productivity threshold above which FDI is profitable. As firms from non-OECD countries are on average less productive than firms from OECD countries, the probability that the productivity of such firms will exceed the productivity threshold is lower than for firms from OECD countries.

The theoretical model proposes that institutional distance also reduces the profitability of investment and the volume of FDI undertaken. The empirical results validate this proposition. In addition, our 
results show that the sensitivity of FDI volume to institutional distance is similar for OECD and nonOECD firms. The effect of institutional distance on the profitability of investment is thus similar for OECD and non-OECD countries.

\section{Conclusion}

We propose a theoretical model to explain the impact of institutional distance on FDI. We assume that institutional distance imposes a cost on investors. Precisely, investors must interact with foreign institutions to obtain credit and complete administrative, bureaucratic, and legal procedures when investing abroad; institutional proximity increases the expertise available to cope with these procedures. The model suggests that institutional distance influences both the decision to invest abroad (extensive margin) and the volume of investment a firm undertakes (intensive margin). As adaptation costs increase with institutional distance between source and host countries, institutional distance determines the productivity threshold at which FDI is more profitable than exporting as a means of entering a foreign market. Increases in institutional distance raise this threshold and the number of firms that undertake FDI decreases. In addition, institutional distance also affects the total volume of FDI undertaken by the source country in the host economy by affecting the extensive margin and firms' profitability.

We conduct an empirical investigation to validate our model, using data on FDI of OECD countries. Using alternative indicators of institutional distance, the results suggest that both the extensive and intensive margins of FDI decrease as institutional distance increases. Institutional distance plays an important role in FDI. First, institutional distance reduces the number of firms for which FDI is sufficiently profitable that they prefer exporting over this mode of implantation. Second, institutional distance reduces the profitability of FDI such as the amount of firms' FDI decreases with this distance.

Institutional distance has differing effects on OECD countries' outward and inward FDI. In particular, institutional distance is more important for OECD countries' inward FDI than for their outward FDI. This indicates that there is an asymmetry in bilateral FDI flows between developed and developing 
countries. Perceived institutional distance from a developed country to a developing country and from the same developing to the developed country are not equal. Firms from developed countries can more easily cope with the costs of institutional distance, which explains why FDI flows from developed countries are larger than FDI flows from developing countries.

In addition to institutional distance, differences in economic size and in geographical and cultural distance discourage FDI. So, to date, proximity has been a major determinant of bilateral FDI. As cultural and economic proximity cannot be modified in the short run, authorities in developing countries should focus on improving institutions to improve FDI performance. 


\section{References}

Acemoglu, D. \& Robinson, J. (2010). The Role of Institutions in Growth and Development. Review of Economics and Institutions, 1 (2), Article 1. doi:10.5202/rei.v1i2.1.

Algan, Y. \& Cahuc, P. (2010). Inherited Trust and Growth. American Economic Review, 100(5), 2060 $-92$.

Bénassy-Quéré, A., Coupet, M. \& Mayer, T. (2007). Institutional Determinants of Foreign Direct Investment. The World Economy, 30(5), $764-782$.

Bergstrand, J. H. \& Egger, P. (2007). A knowledge-and-physical-capital model of international trade flows, foreign direct investment, and multinational enterprises. Journal of International Economics, $73(2), 278-308$.

Daude, C. \& Stein, E. (2007). The quality of institutions and foreign direct investment. Economics \& Politics, 19, $317-344$.

Guiso, L., Sapienza, P. \& Zingales, L. (2009). Cultural Biases in Economic Exchange? Quarterly Journal of Economics, 124(3), 1095-1131.

Habib, M. \& Zurawicki, L. (2002). Corruption and Foreign Direct Investment. Journal of International Business Studies, 33(2), 291 - 307.

Head, K. \& Ries, J. (2008). FDI as an outcome of the market for corporate control: Theory and evidence. Journal of International Economics, 74(1), 2 - 20.

Helpman, E., Melitz, M. \& Rubinstein, Y. (2008). Estimation trade flows: trading partners and trade volumes. The Quarterly Journal of Economics, 123 (2), 441-487.

Helpman, E., Melitz, M. \& Yeaple, S. (2004). Export Versus FDI with Heterogeneous Firms. American Economic Review, 94(1), $300-316$.

Johanson, J. \& Vahlne, J. (2009). The internationalization process of the firm - a model of knowledge development and increasing foreign market commitments. Journal of International Business 
Studies, 40(9), 1411-1431.

Kleinert, J. \& Toubal, F. (2010). Gravity for FDI. Review of International Economics, 18(1), 1 - 13.

Levchenko, A. (2007). Institutional Quality and International Trade. Review of Economic Studies, 74(3), $791-819$.

Melitz, M. (2003). The impact of trade on intra-industry reallocations and aggregate industry productivity. Econometrica, 71 (6), 1695-1725.

North, D. (1993). Economic Performance Through Time. Nobel Prize Lecture (9 December).

Santos-Silva, J. M. C. \& Tenreyro, S. (2010). On the existence of the maximum likelihood estimates in Poisson regression. Economics Letters, 107, 310 - 312.

UNCTAD (2012). World Investment Report 2012: Towards a New Generation of Investment Policies. United Nations Conference on Trade and Development (UNCTAD). New York and Geneva: United Nations publication.

Yeaple, S. (2009). Firm heterogeneity and the structure of U.S. multinational activity. Journal of International Economics, 78(2), $206-215$.

Wooldridge, J.M. (2002). Econometric Analysis of Cross Section and Panel Data. MIT Press. 
Figure 1. Productivity thresholds and profits from exporting and FDI.

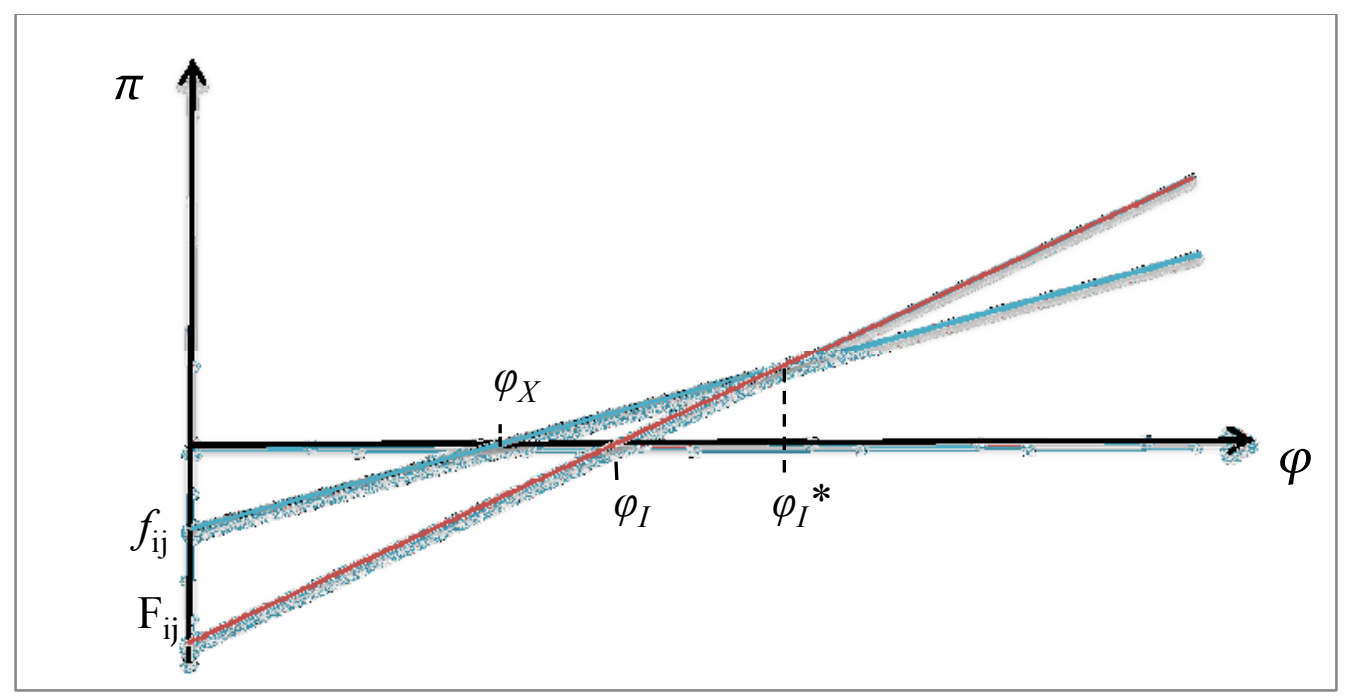

Table 1. Institutional indexes

\begin{tabular}{lcc}
\hline \hline Variables & Index 1 & Index 2 \\
\hline Corruption & Yes & Yes \\
Government effectiveness & Yes & Yes \\
Political stability & Yes & Yes \\
Regulatory quality & Yes & Yes \\
Credit rights & Yes & Yes \\
Information index & Yes & Yes \\
Cost to execute a contract & & Yes \\
Cost to register a property & & Yes \\
Cost to start a business & & Yes \\
Cost to export & & Yes \\
Cost to import & & Yes \\
Protectionist policy & & Yes \\
Private credit & & Yes \\
\hline
\end{tabular}


Table 2. Extensive and intensive margins of outward FDI

\begin{tabular}{|c|c|c|c|c|c|c|c|c|c|c|}
\hline $\begin{array}{l}\text { Estimation method } \\
\text { Dependent variable }\end{array}$ & $\begin{array}{r}P P M L \\
F D I_{i j} \\
\quad(1)\end{array}$ & & $\begin{array}{r}\text { Probit } \\
\quad S_{i j} \\
\quad(2)\end{array}$ & & $\begin{array}{r}P P M L \\
F D I_{i j} \\
\quad \text { (3) }\end{array}$ & & $\begin{array}{r}\text { Probit } \\
S_{i j} \\
\quad(4)\end{array}$ & & $\begin{array}{r}P P M L \\
F D I_{i j} \\
\quad \text { (5) }\end{array}$ & \\
\hline Source GDP per capita & $\begin{array}{r}2.283 \\
(0.867)\end{array}$ & $* *$ & $\begin{array}{r}2.347 \\
(0.493)\end{array}$ & $* *$ & $\begin{array}{r}2.662 \\
(0.983)\end{array}$ & $* *$ & $\begin{array}{r}2.347 \\
(0.498)\end{array}$ & $* *$ & $\begin{array}{r}2.608 \\
(0.962)\end{array}$ & $* *$ \\
\hline Host GDP per capita & $\begin{array}{r}1.145 \\
(0.245)\end{array}$ & $* *$ & $\begin{array}{l}-0.131 \\
(0.253)\end{array}$ & & $\begin{array}{r}1.173 \\
(0.264)\end{array}$ & $* *$ & $\begin{array}{r}-0.069 \\
(0.258)\end{array}$ & & $\begin{array}{r}1.118 \\
(0.255)\end{array}$ & $* *$ \\
\hline GDP Similarity & $\begin{array}{r}0.172 \\
(0.055)\end{array}$ & $* *$ & $\begin{array}{r}0.152 \\
(0.037)\end{array}$ & $* *$ & $\begin{array}{r}0.215 \\
(0.051)\end{array}$ & $* *$ & $\begin{array}{r}0.151 \\
(0.037)\end{array}$ & $* *$ & $\begin{array}{r}0.234 \\
(0.049)\end{array}$ & $* *$ \\
\hline Geographical distance & $\begin{array}{r}-0.479 \\
(0.063)\end{array}$ & $* *$ & $\begin{array}{r}-0.717 \\
(0.045)\end{array}$ & $* *$ & $\begin{array}{l}-0.394 \\
(0.052)\end{array}$ & $* *$ & $\begin{array}{l}-0.718 \\
(0.046)\end{array}$ & ** & $\begin{array}{l}-0.402 \\
(0.053)\end{array}$ & $* *$ \\
\hline Contiguity dummy & $\begin{array}{l}-0.022 \\
(0.151)\end{array}$ & & $\begin{array}{r}-0.157 \\
(0.239)\end{array}$ & & $\begin{array}{r}0.039 \\
(0.132)\end{array}$ & & $\begin{array}{l}-0.142 \\
(0.242)\end{array}$ & & $\begin{array}{r}0.027 \\
(0.129)\end{array}$ & \\
\hline Common language dummy & $\begin{array}{r}0.676 \\
(0.133)\end{array}$ & $* *$ & $\begin{array}{r}0.387 \\
(0.096)\end{array}$ & $* *$ & $\begin{array}{r}0.716 \\
(0.115)\end{array}$ & $* *$ & $\begin{array}{r}0.383 \\
(0.096)\end{array}$ & $* *$ & $\begin{array}{r}0.667 \\
(0.110)\end{array}$ & $* *$ \\
\hline Colonial tie dummy & $\begin{array}{r}0.239 \\
(0.138)\end{array}$ & & $\begin{array}{r}1.161 \\
(0.148)\end{array}$ & $* *$ & & & $\begin{array}{r}1.164 \\
(0.149)\end{array}$ & ** & & \\
\hline $\begin{array}{l}\text { Institutional distance } \\
\text { Index } 1\end{array}$ & & & $\begin{array}{r}-0.053 \\
(0.025)\end{array}$ & * & $\begin{array}{r}-0.099 \\
(0.027)\end{array}$ & $* *$ & & & & \\
\hline $\begin{array}{l}\text { Institutional distance } \\
\text { Index } 2\end{array}$ & & & & & & & $\begin{array}{l}-0.056 \\
(0.027)\end{array}$ & $*$ & $\begin{array}{r}-0.093 \\
(0.026)\end{array}$ & $* *$ \\
\hline$\hat{z}_{i j}$ & & & & & $\begin{array}{r}1.144 \\
(0.147)\end{array}$ & $* *$ & & & $\begin{array}{r}1.148 \\
(0.151)\end{array}$ & $* *$ \\
\hline$\hat{z}_{i j}^{2}$ & & & & & $\begin{array}{r}-0.432 \\
(0.102)\end{array}$ & $* *$ & & & $\begin{array}{l}-0.435 \\
(0.104)\end{array}$ & $* *$ \\
\hline$\hat{z}_{i j}^{3}$ & & & & & $\begin{array}{r}0.056 \\
(0.019) \\
\end{array}$ & $* *$ & & & $\begin{array}{r}0.057 \\
(0.019) \\
\end{array}$ & $* *$ \\
\hline Observations & 23064 & & 22755 & & 22755 & & 22476 & & 22476 & \\
\hline $\mathrm{R}^{2}$ & 0.87 & & 0.54 & & 0.89 & & 0.54 & & 0.89 & \\
\hline
\end{tabular}


Table 3. Extensive and intensive margins of inward FDI

\begin{tabular}{|c|c|c|c|c|c|c|c|c|c|c|}
\hline $\begin{array}{l}\text { Estimation method } \\
\text { Dependent variable }\end{array}$ & $\begin{array}{r}P P M L \\
F D I_{i j} \\
\quad(1)\end{array}$ & & $\begin{array}{r}\text { Probit } \\
S_{i j} \\
(2)\end{array}$ & & $\begin{array}{r}P P M L \\
F D I_{i j} \\
\quad(3)\end{array}$ & & $\begin{array}{r}\text { Probit } \\
S_{i j} \\
(4)\end{array}$ & & $\begin{array}{r}P P M L \\
F D I_{i j} \\
\quad \text { (5) }\end{array}$ & \\
\hline Source GDP per capita & $\begin{array}{r}0.775 \\
(0.726)\end{array}$ & & $\begin{array}{r}-0.346 \\
(0.259)\end{array}$ & & $\begin{array}{r}0.907 \\
(0.734)\end{array}$ & & $\begin{array}{l}-0.341 \\
(0.263)\end{array}$ & & $\begin{array}{r}0.942 \\
(0.712)\end{array}$ & \\
\hline Host GDP per capita & $\begin{array}{r}2.288 \\
(0.575)\end{array}$ & $* *$ & $\begin{array}{r}0.641 \\
(0.494)\end{array}$ & & $\begin{array}{r}2.256 \\
(0.603)\end{array}$ & $* *$ & $\begin{array}{r}0.744 \\
(0.498)\end{array}$ & & $\begin{array}{r}2.201 \\
(0.571)\end{array}$ & $* *$ \\
\hline GDP Similarity & $\begin{array}{r}0.332 \\
(0.064)\end{array}$ & $* *$ & $\begin{array}{r}0.241 \\
(0.039)\end{array}$ & $* *$ & $\begin{array}{r}0.366 \\
(0.067)\end{array}$ & $* *$ & $\begin{array}{r}0.242 \\
(0.039)\end{array}$ & $* *$ & $\begin{array}{r}0.382 \\
(0.064)\end{array}$ & $* *$ \\
\hline Geographical distance & $\begin{array}{r}-0.473 \\
(0.057)\end{array}$ & $* *$ & $\begin{array}{l}-0.616 \\
(0.044)\end{array}$ & $* *$ & $\begin{array}{r}-0.440 \\
(0.046)\end{array}$ & $* *$ & $\begin{array}{r}-0.615 \\
(0.044)\end{array}$ & ** & $\begin{array}{l}-0.464 \\
(0.047)\end{array}$ & $* *$ \\
\hline Contiguity dummy & $\begin{array}{r}0.222 \\
(0.129)\end{array}$ & & $\begin{array}{r}-0.079 \\
(0.200)\end{array}$ & & $\begin{array}{r}0.234 \\
(0.121)\end{array}$ & & $\begin{array}{l}-0.088 \\
(0.202)\end{array}$ & & $\begin{array}{r}0.172 \\
(0.123)\end{array}$ & \\
\hline Common language dummy & $\begin{array}{r}0.525 \\
(0.131)\end{array}$ & $* *$ & $\begin{array}{r}0.476 \\
(0.103)\end{array}$ & $* *$ & $\begin{array}{r}0.564 \\
(0.128)\end{array}$ & $* *$ & $\begin{array}{r}0.475 \\
(0.103)\end{array}$ & $* *$ & $\begin{array}{r}0.537 \\
(0.108)\end{array}$ & $* *$ \\
\hline Colonial tie dummy & $\begin{array}{r}0.159 \\
(0.116)\end{array}$ & & $\begin{array}{r}0.723 \\
(0.146)\end{array}$ & $* *$ & & & $\begin{array}{r}0.733 \\
(0.146)\end{array}$ & $* *$ & & \\
\hline $\begin{array}{l}\text { Institutional distance } \\
\text { Index } 1\end{array}$ & & & $\begin{array}{r}-0.080 \\
(0.025)\end{array}$ & $* *$ & $\begin{array}{r}-0.075 \\
(0.029)\end{array}$ & * & & & & \\
\hline $\begin{array}{l}\text { Institutional distance } \\
\text { Index } 2\end{array}$ & & & & & & & $\begin{array}{l}-0.106 \\
(0.027)\end{array}$ & ** & $\begin{array}{l}-0.109 \\
(0.028)\end{array}$ & $* *$ \\
\hline$\hat{z}_{i j}$ & & & & & $\begin{array}{r}1.153 \\
(0.207)\end{array}$ & $* *$ & & & $\begin{array}{r}1.136 \\
(0.211)\end{array}$ & $* *$ \\
\hline$\hat{z}_{i j}^{2}$ & & & & & $\begin{array}{l}-0.605 \\
(0.134)\end{array}$ & $* *$ & & & $\begin{array}{l}-0.597 \\
(0.134)\end{array}$ & $* *$ \\
\hline$\hat{z}_{i j}^{3}$ & & & & & $\begin{array}{r}0.091 \\
(0.024) \\
\end{array}$ & $* *$ & & & $\begin{array}{r}0.089 \\
(0.024) \\
\end{array}$ & $* *$ \\
\hline Observations & 23064 & & 22755 & & 22755 & & 22476 & & 22476 & \\
\hline $\mathrm{R}^{2}$ & 0.90 & & 0.57 & & 0.90 & & 0.57 & & 0.91 & \\
\hline
\end{tabular}

